\title{
SEISMIC CAPACITY OF RC FRAME BUILDINGS WITH MASONRY INFILL DAMAGED BY PAST EARTHQUAKES
}

\author{
Hamood Alwashali ${ }^{1}$, Md. Shafiul Islam ${ }^{2}$, Debasish Sen ${ }^{3}$, \\ Jonathan Monical ${ }^{4}$ and Masaki Maeda ${ }^{5}$
}

(Submitted August 2019; Reviewed September 2019; Accepted November 2019)

\begin{abstract}
Many of the buildings which experienced damage in recent earthquakes such as the 2015 Nepal Earthquake were reinforced concrete (RC) frame buildings with unreinforced masonry infill walls. This study proposes a simplified procedure to estimate the in-plane seismic capacity of masonry infilled RC frame buildings based on concepts of the Japanese seismic evaluation standard (JBDPA, [1]). The correlation of seismic capacity and observed damage obtained using a database of 370 existing RC frame buildings with masonry infill that experienced earthquakes in Taiwan, Ecuador and Nepal is investigated. The $I_{s}$ index, which represents the seismic capacity of buildings in the Japanese standard, showed good correlation with the observed damage and proved to be effective as a simple method to estimate seismic capacity. The method was then applied to 103 existing buildings in Bangladesh that have not experienced a major earthquake recently. The results emphasize the necessity for urgent seismic evaluation and retrofitting of buildings in Bangladesh.
\end{abstract}

\section{INTRODUCTION}

Rapid development in the seismic design of RC buildings enabled newly designed buildings to avoid severe damage or collapse. However, there is still a large stock of old buildings designed according to old designed codes. Not all existing old buildings are vulnerable, but their seismic capacity need to be assessed and if necessarily retrofitted. In this regard, Japan had developed a practical standard for seismic evaluation for existing RC buildings (Japan Building Disaster Prevention Association, JBDPA, 2001, [1]) based on it long experiences with devastating earthquakes. The standard has proved its effectiveness in the Great East Japan Earthquake of 2011 where most of the evaluated buildings, that were retrofitted, if necessary, based on the standard evaluation, showed good performance and retrofits prevented severe structural damage as shown in study by [2].

The simplicity and effectiveness of the Japanese standard [1] make it an attractive method to evaluate the seismic capacity of existing buildings in other countries and this was the main motivation of this study. However, the buildings in other countries may have different characteristics from the Japanese buildings and thus the standard cannot be applied directly. In this regard, a procedure that incorporates the effect of masonry infill walls as lateral force resisting members is not mentioned in the standard because masonry walls are not commonly constructed in Japan. Many of the damaged buildings in earthquakes such as the 2008 China Wenchuan Earthquake, the 2015 Nepal Earthquake and the 2017 Mexico Earthquake were reinforced concrete buildings with partition walls and cladding walls made of masonry walls as shown in Figure 1. Masonry infill walls were commonly considered to be non-structural elements and the structures were designed as RC moment resisting frames ignoring the influence of walls. But masonry infill walls can completely change the behaviour of structures as noted by many researchers in several studies such as (Paulay and Preistley [3]). There is a need to estimate the capacity of different orientations of masonry infill walls in other countries to identify buildings that are vulnerable to damage during earthquakes. In addition to the masonry infill walls, the seismicity level is unique to each country. Thus, an appropriate seismic capacity based on the seismic demands of a region would need to be estimated based on past damage data

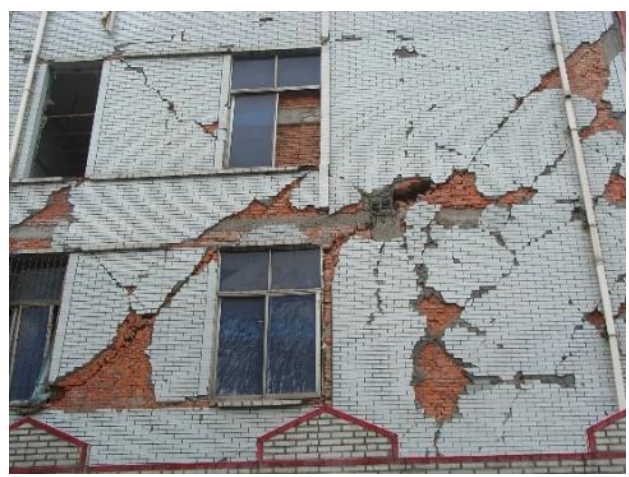

Figure 1: Damage of RC building with masonry infill walls in China 2008 Wenchuan Earthquake.

The purpose of this study is twofold: First, propose a simplified procedure to estimate in-plane strength and ductility of masonry infill based on a review of experimental results. Second, evaluate the proposed procedure to estimate the seismic capacity of 473 existing RC buildings in several countries (Taiwan, Ecuador, Nepal and Bangladesh) based on the evaluation methods of the Japanese standard. The seismic capacity of the buildings in the database and its correlation to observed damage are investigated and recommendations for seismic criteria are discussed.

\section{OVERVIEW OF THE JAPANESE STANDARD}

The Japanese standard for seismic evaluation of existing RC building has been widely used since its first publication in 1977, [4]. Another two editions with partial revisions in 1990 and 2001 followed. Application of the standard to existing

\footnotetext{
${ }^{1}$ Assistant Professor, Tohoku University, Sendai Japan, Hamood@ rcl.archi.tohoku.ac.jp.

2 Ph.D. candidate, Tohoku University, Sendai Japan, Shafiul@rcl.archi.tohoku.ac.jp

3 Ph.D. candidate, Tohoku University, Sendai Japan, Dsendip@rcl.archi.tohoku.ac.jp

4 Ph.D. candidate, Purdue University, West Lafayette, United States, Jmonica@purdue.edu

5 Professor, Tohoku University, Sendai Japan, Maeda@rcl.archi.tohoku.ac.jp
} 
buildings greatly increased after the 1995 Kobe Earthquake which included enforcement of the law for promotion of seismic retrofit of buildings and seismic evaluation all over Japan.

The JBDPA standard has three screening levels. The $1^{\text {st }}$ level is the simplest and most conservative, and the $3^{\text {rd }}$ level is the most complex with detailed calculations. In the $1^{\text {st }}$ level screening, only the strength of concrete and the sectional areas of columns and walls are considered to estimate the seismic capacity. This study will focus on the $1^{\text {st }}$ level evaluation since the investigated database of existing buildings has simple drawings showing only basic information.

Only an overview of the concept of the standard is presented here. More details about the Japanese standard are discussed in previous studies such as [4,5]. The seismic capacity of a building is expressed by the $I_{s}$ index and is calculated by Eq. 1 for each story.

$$
I_{s}=E_{o} \cdot S_{D} \cdot T
$$

$S_{D}$ and $T$ are reduction factors that modify the basic seismic index of a structure $\left(E_{o}\right)$ because of structural irregularity and deterioration after construction, respectively. $E_{o}$ is the product of the strength index $(C)$, ductility index $(F)$ and story index $(n+1 / n+i)$ as shown in Eq. 2, for $1^{\text {st }}$ level evaluation.

$$
E_{o}=\frac{n+1}{n+i} \cdot\left(C_{1}+\alpha_{2} C_{2}+\alpha_{3} C_{3}\right) \cdot F_{1}
$$

$C$ is the strength index that denotes the story-shear coefficient of each structural member, where $C_{1}, C_{2}$, and $C_{3}$ represent three different types of structural members with different deformation capacities. $F$ is the ductility index of each member ranging from 0.8 (extremely brittle) to 3.2 (most ductile), based on the inelastic capacity expected of each structural member. $F$ index in for RC columns depends on the sectional properties such as bar arrangement, shear-to-flexural-strength ratio etc. In Eq.2, $C_{1}$ and $F_{1}$ represent the stiffest member with limited deformation capacity which is expected to fail first. $(n+1) /(n+i)$ is the story index which accounts for the mode shape of the response along the building height. $\alpha$ is the effective strength factor which reduces the effective strength of ductile members at ultimate deformation of stiff members, where $\alpha_{2}, \alpha_{3}$, represent the effective strength factors for $C_{2}$ and $C_{3}$ which are considered to have larger deformation capacity than $C_{l}$.

The calculation procedures of $F$ index (ductility index) and $C$ index (strength index) for structural members for each evaluation level is different, where simple and conservative estimation is used in the $1^{\text {st }}$ level evaluation and more detailed calculations in the $3^{\text {rd }}$ level. The next section investigates and propose evaluation procedure of $C$-index and F-index for masonry infill for the $1^{\text {st }}$ level screening.

\section{SEISMIC CAPACITY OF MASONRY INFILL}

\section{Lateral Strength and $C$-Index of Masonry Infill}

The proposed evaluation considers masonry infill and boundary columns as two separate elements. This is assumed because masonry infill eventually delaminates from the surface of the surrounding columns and may fail before the boundary columns. Thus, the $C$-index of masonry infill and $C$-index of columns are calculated separately. If ductile enough, the columns would continue to carry the lateral load and would fail at a larger drift as shown in Figure 2.

$C_{\text {masonry }}$ for the $1^{\text {st }}$ level evaluation for every element is shown in Eq. 3.

$$
C_{\text {masonry }}=\frac{\mathrm{Q}_{\mathrm{u}}}{\sum \mathrm{W}}=\frac{\tau_{\text {inf }} \cdot A_{\text {inf }}}{\sum \mathrm{W}}
$$

In this equation, $Q_{u}$ is the ultimate lateral load-carrying capacity of masonry infill. $\sum W$ is the weight of the building supported by the story. $\tau_{\text {inf }}$ is the shear strength of masonry. $A_{\text {inf }}$ is the cross-sectional area of the masonry infill panel taken as the product of $l_{\text {inf }}$ (infill panel length) and $t_{\text {inf }}$ (thickness of infill). The calculation of the cross-sectional area, $A_{\text {inf }}$, and the weight of the building are straightforward. However, the estimation of the shear strength of the infill, $\tau_{i n f}$, varies greatly based on the type and quality of masonry.

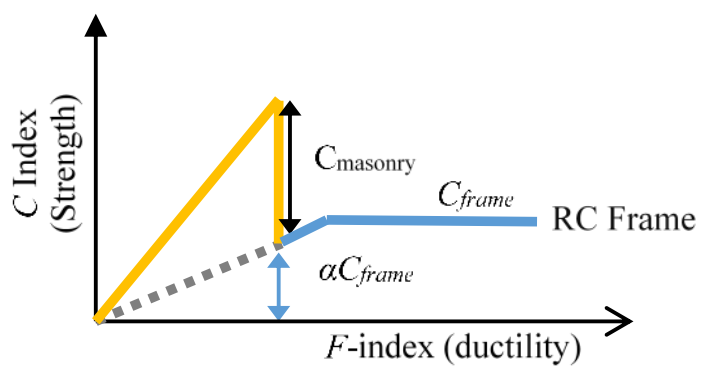

Figure 2: Main concept of calculating $C$-index of masonry infill.

This paper briefly discusses the results of past experimental studies in order to understand the parameters influencing the shear strength of masonry infill. Figure 3 shows the relation between the shear strength of the masonry infill and the masonry prism compressive strength, $f_{m}$, based on a database of experimental results from nine different researchers [6-14] and details of the experimental results are summarized in [15]. The database consists of single-story, single-span RC frames with masonry infill tested under static cyclic loading with several types of masonry bricks. As shown in Figure 3, the shear strength of the masonry infill, $\tau_{i n f}$, generally ranges between 0.2 and $1 \mathrm{~N} / \mathrm{mm}^{2}$. The shear strength, $\tau_{\text {inf }}$ commonly ranges between $0.04 f_{m}$ and $0.1 f_{m}$.

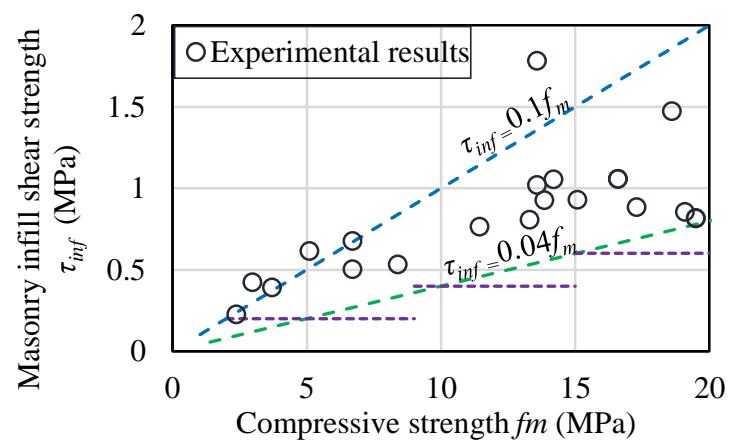

\section{Figure 3: Relation of prism compressive strength to shear strength of masonry infill.}

Another important parameter influencing the shear strength of masonry infill is the ratio of lateral strength of boundary frame to shear strength of masonry infill. In general, a strong boundary RC frame around the masonry infill will increase the confinement of masonry infill and thus increase its shear strength. To classify the frames into weak and strong ones, the $\beta$ index is used, which is defined in this study, as shown in Eq. 4. $\beta$-index is the ratio of expected bare frame lateral strength to the expected masonry infill strength as shown in Eq.4.

$\beta=V f / V$ inf

Where $V_{f}$ is the lateral strength of boundary frame which is calculated to be the ultimate flexural capacity, assuming plastic 
hinges at the ends of the column as in bare frame (or plastic hinges at the end of the beams in the case of weak beam and strong column). $V_{i n f}$ is the expected lateral capacity of infill, computed by Eq. 5 . This is a simple prediction assuming the $\tau_{\text {inf }}$ as $0.05 f_{m}$. This value gives an average value of experimental to analytical results of 0.83 as shown in the study [15].

$$
V_{\text {inf }}=0.05 f_{m} \cdot t_{\text {inf }} \cdot l_{\text {inf }}
$$

Figure 4 shows the relation between $\beta$-index (ratio of frame strength to masonry strength) and increase in masonry shear strength, $\tau_{\text {inf }}$ (Normalized shear strength by dividing by prism compressive strength, $f_{m}$ ).

Evaluating the $\beta$-index requires some investigative effort such as knowing the reinforcement details of the RC frame. In this paper, the scope was limited to the simplified $1^{\text {st }}$ level evaluation, thus the influence of the $\beta$-index was ignored and the lower bound of shear strength is used. A more detailed evaluation method considering the $\beta$-index is proposed elsewhere [15].

Additionally, acquiring the data of the prism compressive strength of masonry infill in the site, might be difficult during $1^{\text {st }}$ level evaluation process. Therefore, for simplicity in the absence of material test results from the field, the shear strength of masonry infill in the first level evaluation is proposed to be taken as the lower boundary of expected masonry compressive strength as shown in Table 1 and Figure 3.

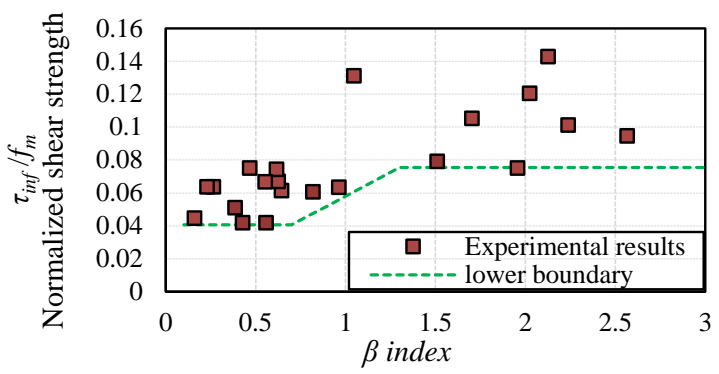

(bare frame strength/ expected masonry strength )

Figure 4: Relation of $\beta$ index to shear strength of infill.

Table 1: Proposed shear strength of masonry infill for First level evaluation.

\begin{tabular}{|c|c|}
\hline $\begin{array}{c}\text { Compressive strength of } \\
\text { masonry } f m\left(\mathrm{~N} / \mathrm{mm}^{2}\right)\end{array}$ & $\begin{array}{l}\text { Proposed shear strength of } \\
\text { masonry infill }\left(\mathrm{N} / \mathrm{mm}^{2}\right)\end{array}$ \\
\hline $3<f_{m}<9$ & 0.2 \\
\hline $9<f_{m}<15$ & 0.4 \\
\hline$f_{m}>15$ & 0.6 \\
\hline
\end{tabular}

\section{Ductility of Masonry Infill and Proposed F Index}

This paper briefly discuss the results related to deformation limits for masonry infill based on database of experimental studies [6-14], that are summarized in [15]. $R_{\max }$ and $R_{u}$, represent the story drift at maximum strength and story drift when the lateral strength degraded to $80 \%$ of maximum lateral strength, respectively. $R_{\max }$ has an average of $0.72 \%$ and standard deviation of $0.36 \% . R_{u}$ has an average of $1.71 \%$ and standard deviation of $0.77 \%$.

There are several parameters influencing the deformation limits of masonry infill such as brick type, mortar strength and the relative strength of the surrounding frame. An important parameter is the $\beta$-index (indicating the relative strength of frame to masonry infill strength as shown in Eq. 4). Figure 5 shows the relation between the $\beta$-index and $R_{u}$. A higher $\beta$-index (relatively stronger frame) would correspond to a greater ductility and $\beta<0.5$ (relatively weak frame) would indicate lower ductility. Such a relation between deformation limits and $\beta$-index was also noted in other seismic evaluation standards such as ASCE/SEI [16] and NZSEE assessment guideline [17].

Also, experimental results showed that specimens with values of $\beta<0.5$ (relatively strong infill and weak frame) showed brittle response and a sudden drop of strength after reaching its maximum strength as shown in Figure 6 which shows test specimen F-0.4 in [14].

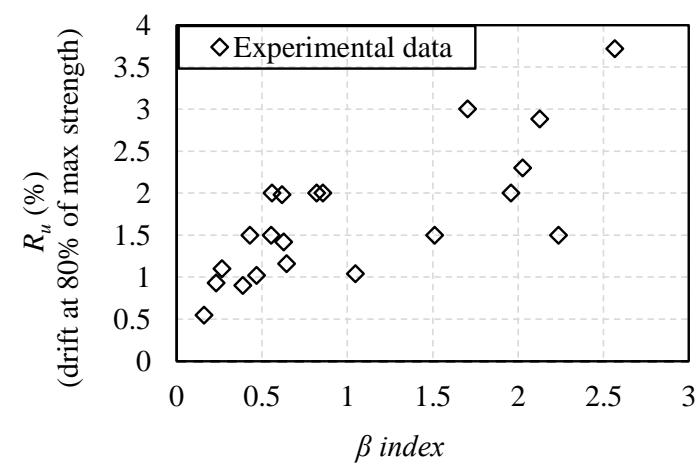

Figure 5: Relation of between $\beta$-index and $R_{u}$ drift.

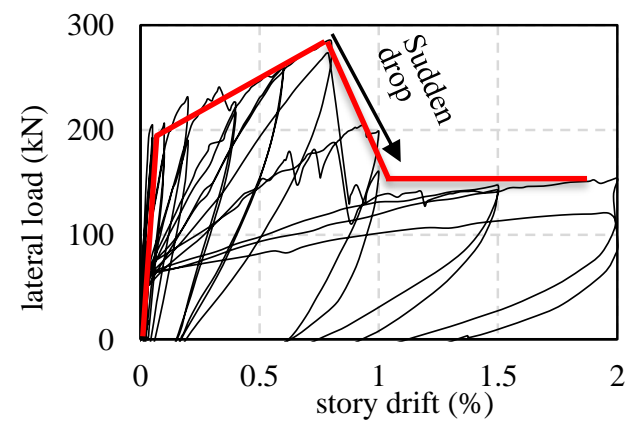

Figure 6: Specimen with $\beta<0.5$ (weak frame).

The $1^{\text {st }}$ level screening in the Japanese standard conservatively limits the ductility index to a maximum value of $F=1$ for ductile vertical-resisting elements (RC columns and $\mathrm{RC}$ walls). This corresponds to a story drift of about $0.4 \%$. In other words, the columns and $\mathrm{RC}$ walls are assumed to fail as brittle elements at a story drift of about $0.4 \%$. As this study focuses on the $1^{\text {st }}$ level evaluation, the $F$-index for masonry infill is taken as 1 and the influence of the $\beta$-index is conservatively ignored.

A more detailed evaluation of the $F$-index for masonry infill for the $2^{\text {nd }}$ level screening is discussed in another study by the author [15].

\section{APPLICATION OF THE EVALUATION METHOD}

Three different recent earthquakes in Taiwan, Ecuador and Nepal are investigated. These countries were selected based on the availability of documented damage data. The data are collected from an open data website named Datacenterhub [1820]. The data is from field surveys of RC buildings damaged by the earthquakes collected as a reconnaissance effort led by the American Concrete Institute (ACI) and several other organizations. The data of the buildings contains locations with GPS coordinates, simple sketches of plans for each building 
showing cross-sectional areas of columns and masonry infill, and photos of damage.

The classification of damage level of the buildings in the database is as follows:

I. Light: Hairline (crack width $<0.13 \mathrm{~mm}$ ) inclined and flexural cracks were observed in structural elements.

II. Moderate: Wider cracks or spalling of concrete.

III. Severe: At least one element had a structural failure.

As the database does not contain detailed drawings or material specifications, the following assumptions are used in the calculations:

a) The average weight per unit area of RC buildings is taken as $11 \mathrm{kN} / \mathrm{m}^{2}$ in the absence of data.

b) The effective strength factor used for columns, $\alpha$, is 0.7 , (Figure 2 and Eq. 2), which is recommended in an experimental study by [21].

c) The shear strength of columns commonly ranges $0.7 \mathrm{~N} / \mathrm{mm}^{2} \sim 1.5 \mathrm{~N} / \mathrm{mm}^{2}$, which is indicated in the Japanese standard [1]. In this study, an average of $1 \mathrm{~N} / \mathrm{mm}^{2}$ is used if no material property data exists. However, in this study, the $1 \mathrm{~N} / \mathrm{mm}^{2}$ is then multiplied by $\alpha$ index (see Figure 2) taken as 0.7 in Eq. (2), which indicates that the actual shear strength of columns is taken as $0.7 \mathrm{~N} / \mathrm{mm}^{2}$.

d) The strength contribution of masonry infill walls with large openings (greater than $40 \%$ ) is ignored. The cross-sectional area of infill, $A_{\text {inf }}$, is calculated by deducting cross-sectional area of the openings. In addition, the location of opening is also important, partial infill walls and masonry wall that are not surrounded by RC frame from all sides are ignored.

e) $S_{D}$ and $T$ (reduction factors for structural irregularity and deterioration after construction respectively) are taken as 1 for simplicity.

f) Masonry infill is commonly confined by the boundary columns and thus in-plane failure is considered to occur prior to out-of-plane failure. This assumption is considered based on two main reasons: first, several experimental studies and observations of performance of infill panels under out-of-plane loads conducted by several studies that showed a significant out-of-plane resistance due to the formation of an arching mechanism [22-24]. The other reason is the observation of the photos showing damage of the investigated buildings shown in [18-20] which showed that failure of masonry infill was generally in-plane failure.

Using the above consideration and assumptions into Eq. 1 and Eq. 2, and considering the $1^{\text {st }}$ story of a building, then the seismic capacity, $I_{s}$ index, is taken as Eq.6:

$I_{s}=\left(C_{\text {masonry }}+\alpha C_{\text {column }}\right) \cdot F_{\text {masonry }}$

As discussed previously, $F_{\text {masonry }}$ is taken as 1 and $\alpha$ is taken as 0.7 , for $1^{\text {st }}$ level evaluation.

\section{Taiwan Earthquake 2016}

\section{Overview of the Data and the Earthquake}

An earthquake of magnitude 6.7 occurred in Meinong, Taiwan on February 6, 2016. The earthquake caused large-scale damage in Tainan city which was $40 \mathrm{~km}$ from the epicenter. The data of damaged existing RC buildings are provided by (Datacenter hub [18]). A total of $65 \mathrm{RC}$ buildings with masonry infill are investigated in this study and their locations are shown in Figure 7.
Several ground motion stations in Tainan city recorded values of PGA between $0.2 \mathrm{~g}$ and $0.4 \mathrm{~g}$. The maximum recorded peak ground acceleration (PGA) was $0.45 \mathrm{~g}$ and was measured by station CHY 62. The response acceleration plots use 5\% damping and are shown in Figure 8. Most of the response spectra have values of acceleration less than $0.8 \mathrm{~g}$ for short periods (less than 0.5 seconds), except for station CHY 62.

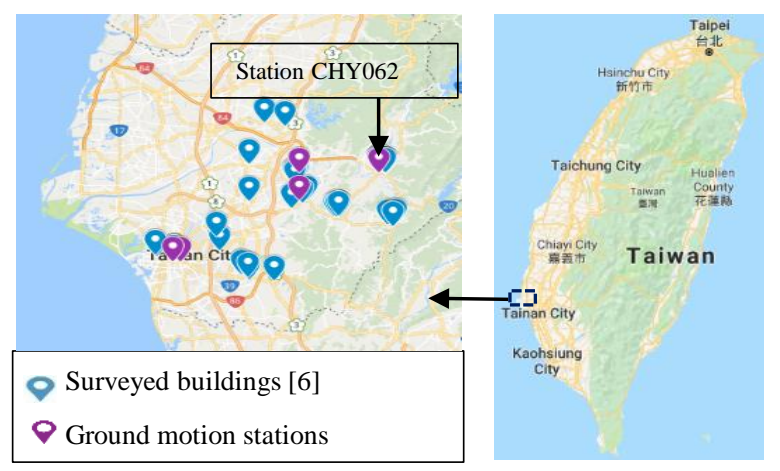

Figure 7: Locations of the investigated buildings.

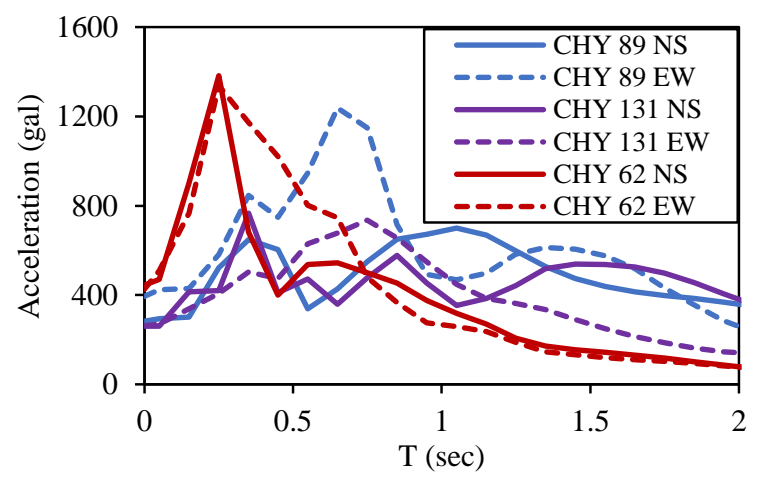

Figure 8: Acceleration response spectra in Taiwan EQ.

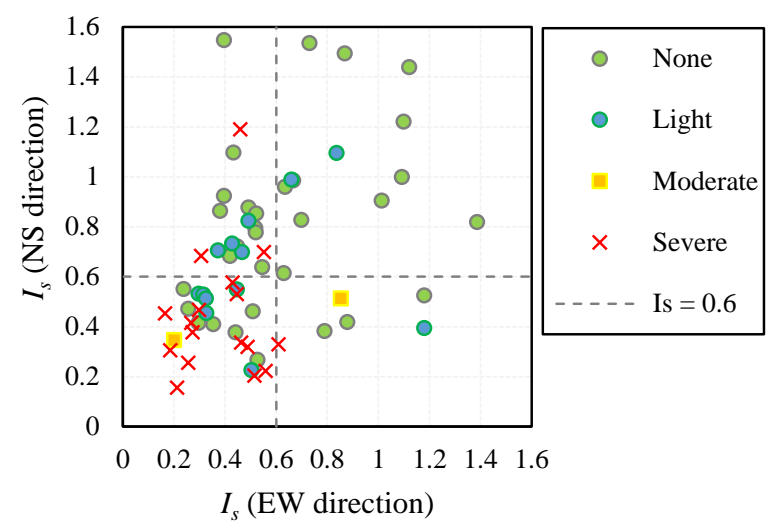

Figure 9: Relation of Is-index and damage in Taiwan EQ.

The number of stories ranged between one and five stories, with the majority of buildings having two or three stories. Details of the investigated buildings are stated in [15]. Masonry infill walls in Taiwan are commonly made of red clay bricks and are 200 to $300 \mathrm{~mm}$ thick. The types and strengths of masonry infill were not stated in the database, but have been stated in several studies such as [25], an expected shear strength of $0.4 \mathrm{~N} / \mathrm{mm}^{2}$ is used for seismic evaluation. 


\section{Seismic Capacity Results for Taiwan EQ}

Figure 9 shows the $I_{s}$-indices for North-South (NS) and EastWest (EW) directions in the $1^{\text {st }}$ story of the investigated buildings with observed damage levels. Figure 10 shows the variation of the $I_{s}$-index with number of buildings. There is a clear trend between damage level and low values of the $I_{s}$-index. In Japan, the $I_{s 0}$-index (demand criteria) is 0.8 and 0.6 for $1^{\text {st }}$ and $2^{\text {nd }}$ level screening, respectively.

Table 2 shows the average and standard deviation of the $I_{s-}$ index for the investigated buildings. Figure 11 shows the lognormal distribution. For severely damaged buildings in Figure 11 shows the ratio of severely damaged buildings to all buildings, the curve of which is adjusted by multiplying the values by ratio 17/65 (severely damaged/ all surveyed buildings). An $I_{s}$-index of 0.5 or 0.6 would be sufficient to avoid severe damage. However, the problem is that most of the investigated buildings, as shown in Figure 11, have seismic capacities lower than 0.6 and retrofitting such large stock of buildings would be expensive.

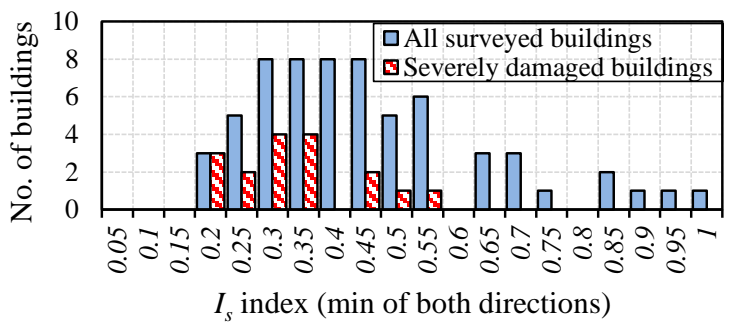

Figure 10: Distribution of $I_{s}$ index in Taiwan EQ.

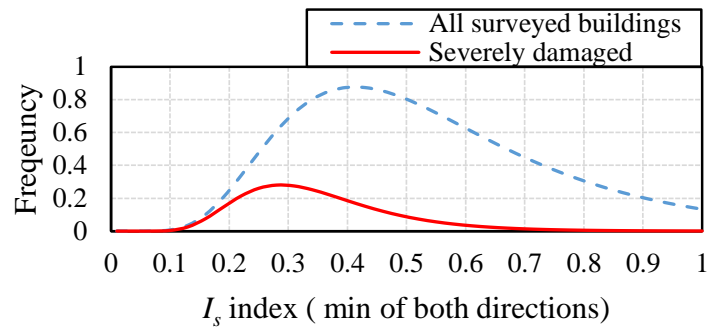

Figure 11: Normal distribution of Is index in Taiwan EQ.

Table 2: Average Is-index of buildings in Taiwan EQ 2016.

\begin{tabular}{|c|c|c|}
\cline { 2 - 3 } \multicolumn{1}{c|}{} & All buildings & Severely damaged \\
\hline Number of bldgs. & 65 & 17 \\
\hline $\begin{array}{c}\text { Average } I_{s} \text { index } \\
\text { (min direction) }\end{array}$ & 0.458 & 0.306 \\
\hline standard deviation & 0.221 & 0.11 \\
\hline
\end{tabular}

\section{Ecuador Earthquake 2016}

\section{Overview of the Data and the Earthquake}

An earthquake with a moment magnitude $M_{w}=7.8$ occurred in Ecuador on April 16, 2016. The reconnaissance data consists of 171 low-rise RC buildings in the cities of Manta, Portoviejo, Chone, and Bahía de Caráquez which are located in the province of Manabí [19], as shown in Figure 12.
The acceleration response spectra using 5\% damping are shown in Figure 13. The acceleration record comes from the ground motion station AMNT and it is the nearest station to the surveyed buildings in Manta city. The acceleration response for buildings with short periods (less than 0.5 seconds) in NS and EW directions exceeded $1 \mathrm{~g}$.

The masonry infill type is not stated in the database, but as noticed from photos of the survey, both concrete blocks and burnt clay bricks are commonly used. In a study by [26], it was found that solid clay bricks had unit compressive strengths between 7.3 and $7.9 \mathrm{MPa}$ and most concrete block units had strengths between 1.0 and $1.5 \mathrm{MPa}$. Thus, the masonry infill shear strength was taken as $0.2 \mathrm{~N} / \mathrm{mm}^{2}$ using the lower bound value as listed in Table 1 .

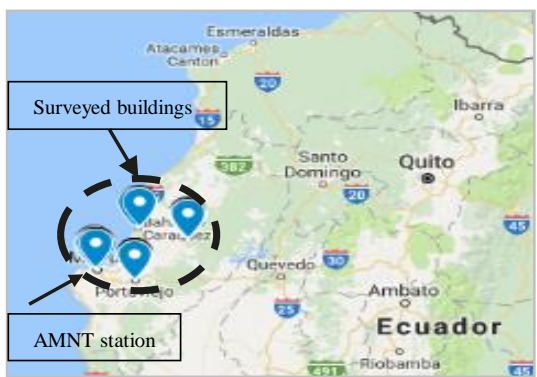

Figure 12: Locations of the investigated buildings.

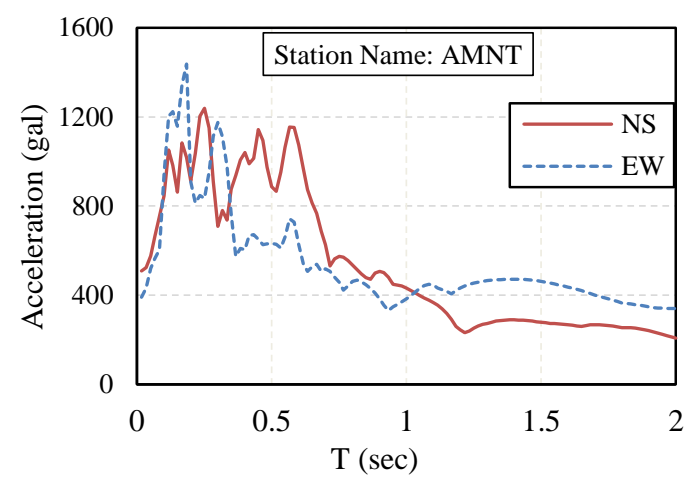

Figure 13: Acceleration spectra in Ecuador EQ.

\section{Seismic Capacity Results in Ecuador EQ}

Figure 14 shows the $I_{s}$-indices for NS and EW directions in the $1^{\text {st }}$ story of the investigated buildings with observed damage levels. Figure 15 shows the variation of $I_{s}$-index with the number of buildings. Table 3 shows the average and standard deviation of the $I_{s}$-index of the investigated buildings. The average $I_{s}$-index of the investigated buildings in Ecuador is 0.32 , which is lower than in Taiwan. Figure 16 shows the logarithmic normal distribution of the $I_{s}$-index. Like Taiwan, buildings with $I_{s}$ index greater than 0.5 avoided severe damage. However, most of the buildings lie below this range as shown in Figure 14.

Table 3: Average Is-index of buildings in Ecuador EQ 2016.

\begin{tabular}{|c|c|c|}
\cline { 2 - 3 } \multicolumn{1}{c|}{} & All buildings & Severely damaged \\
\hline Number of bldgs. & 171 & 77 \\
\hline $\begin{array}{c}\text { Average } I_{s} \text { index } \\
\text { (min direction) }\end{array}$ & 0.316 & 0.255 \\
\hline standard deviation & 0.159 & 0.087 \\
\hline
\end{tabular}




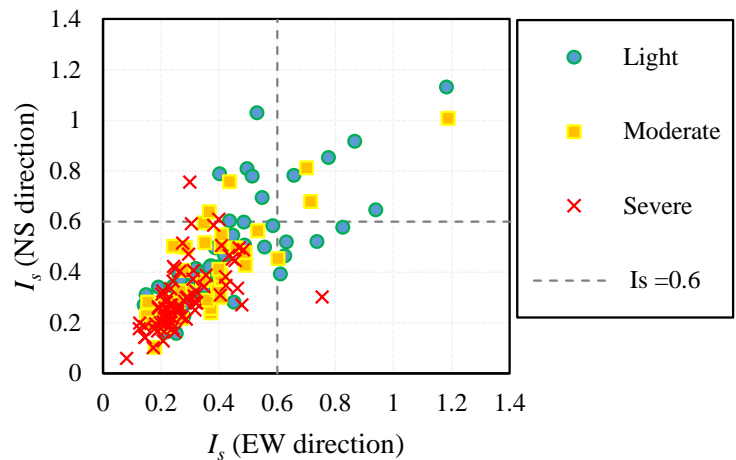

Figure 14: Relation of $I_{s}$-index and damage in Ecuador EQ.

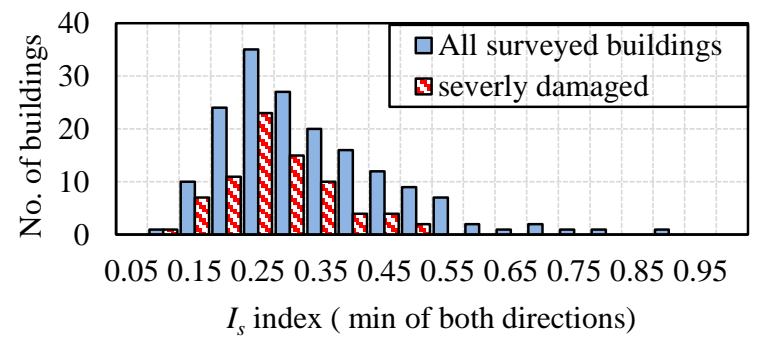

Figure 15: Distribution of $I_{s}$-index in Ecuador EQ.

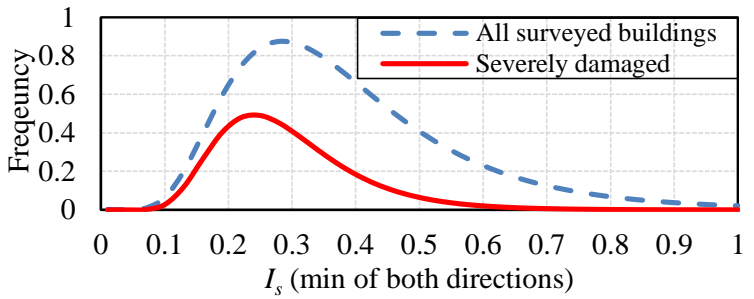

Figure 16: Normal distribution of $I_{s}$-index in Ecuador EQ.

\section{Nepal Earthquake 2015}

\section{Overview of the Data and the Earthquake}

A strong ground shaking with a moment magnitude $\mathrm{Mw}=7.8$ struck near the center of Nepal on April 25, 2015. Surveys of $134 \mathrm{RC}$ buildings with masonry infill located in the capital city, Kathmandu [20] are shown in Figure 17. The response spectra using 5\% damping are shown in Figure 18. The response acceleration spectra for short periods for NS and EW directions is $0.3 \mathrm{~g}$ and $0.6 \mathrm{~g}$, respectively. The ground motion station is relatively near the investigated buildings (Figure 17).

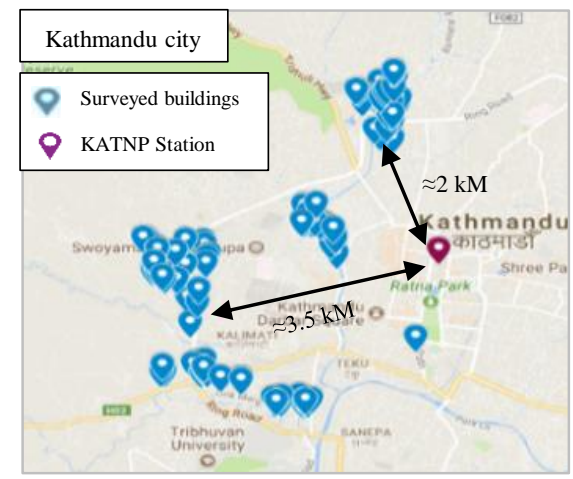

Figure 17: Locations of the investigated buildings.

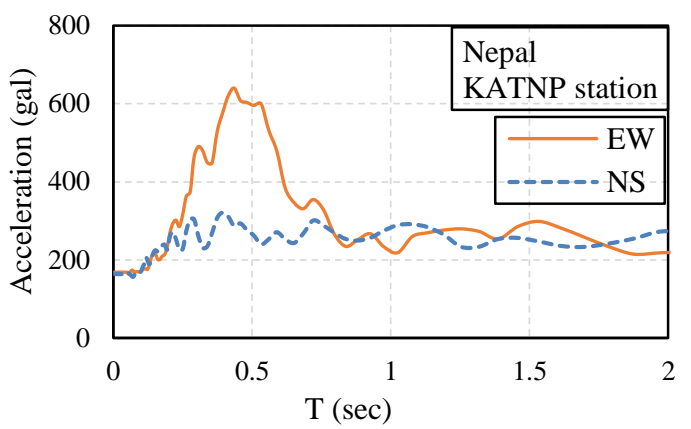

Figure 18: Acceleration response spectra in Nepal EQ.

The damage observed of masonry infilled RC buildings in Nepal Earthquake and construction details are investigated in previous study by [27]. The thicknesses of the masonry infill walls were 110 to $230 \mathrm{~mm}$. The types and strengths of masonry infill were not stated in the database, but it was noticed from the photos of the survey that solid burnt clay bricks were the most common as well as mentioned in the study [27]. The prism compressive strengths of masonry within the same region was investigated in other studies by [28], where the compressive strength was approximately 4.1 MPa. Therefore, the masonry`s shear strength is taken as $0.2 \mathrm{~N} / \mathrm{mm}^{2}$ as listed in Table 1 .

\section{Seismic Capacity Results in Nepal EQ}

Figure 19 shows the $I_{s}$-indices for NS and EW directions in the $1^{\text {st }}$ story of the investigated buildings with observed damage levels. Figure 20 shows the variation of the $I_{s}$-index with the number of buildings. Table 4 shows the average and standard deviation of the $I_{s}$-index of the investigated buildings. Figure 21 shows the log-normal distribution of the $I_{s}$-index. The average seismic capacity of buildings in Nepal is lower than that of buildings in Taiwan and Ecuador. Like Ecuador and Taiwan, the buildings in Nepal with $I_{s}$-indices greater than 0.5 avoided severe damage. It should also be noted that the response acceleration in Nepal is much smaller than that for Taiwan and Ecuador earthquakes as shown in Fig. 18. Thus, in Nepal, an $I_{s^{-}}$ index of 0.5 is relatively high compared with the earthquake demand and this point needs further investigation.

Table 4: Average Is-index of buildings in Taiwan EQ 2015.

\begin{tabular}{|c|c|c|}
\cline { 2 - 3 } \multicolumn{1}{c|}{} & All buildings & Severely damaged \\
\hline Number of bldgs. & 134 & 58 \\
\hline $\begin{array}{c}\text { Average } I_{s} \text { index } \\
\text { (min direction) }\end{array}$ & 0.261 & 0.209 \\
\hline standard deviation & 0.157 & 0.108 \\
\hline
\end{tabular}

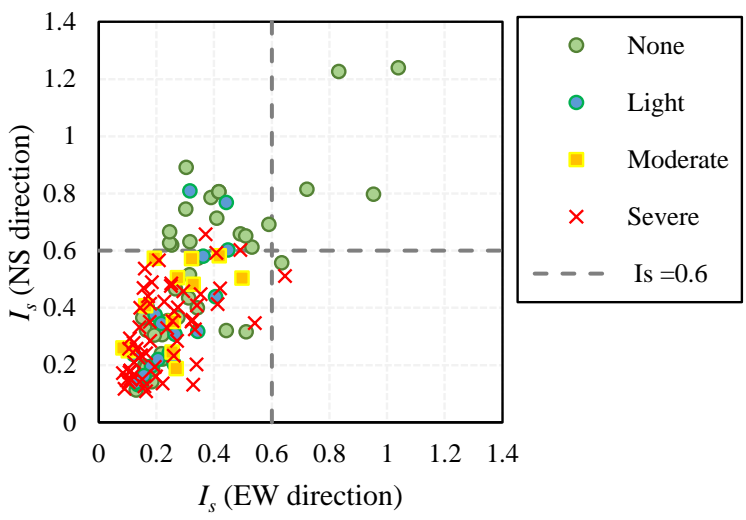

Figure 19: Relation of Is-index and damage in Nepal EQ. 


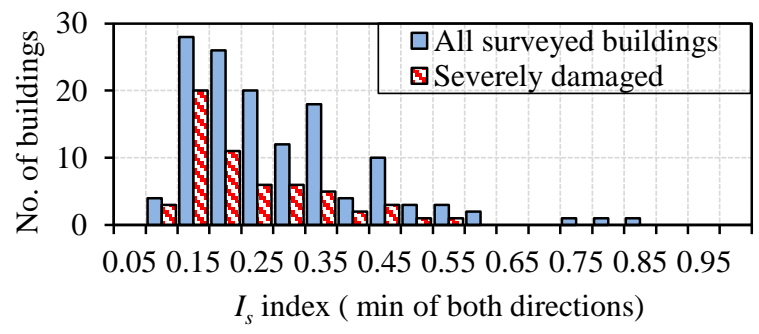

Figure 20: Distribution of Is-index of buildings in Nepal $E Q$.

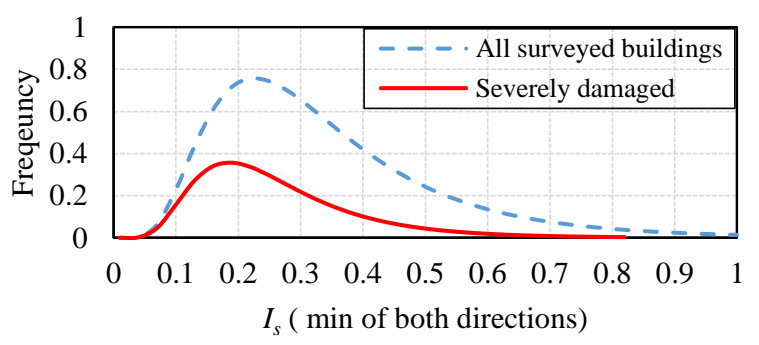

Figure: 21 Normal distribution of Is-index.

\section{APPLICATION IN COUNTRIES WITH NO RECENT EARTHQUAKES}

\section{Overview of the Data in Bangladesh}

Bangladesh is a densely populated country located in a moderately seismic-prone region. The data in this study are collected in Dhaka, the capital city of Bangladesh.

Data from 103 existing RC buildings were collected from two sources:

1 Comprehensive Disaster Management Program (CDMP) collected data between 2010 and 2015 in a collaborative project between the Bangladeshi Ministry of Disaster Management and United Nations Development Program (UNDP). The building data contains sketches of plans of buildings that include dimensions of columns and masonry infill walls. More details included in the database are mentioned in [15].

2 A site investigation for a Japanese project called SATREPSTSUIB 2015 consisted of a team of researchers from Tohoku University including the author and governmental engineers from the Public Works Department in Bangladesh Four existing RC buildings were surveyed in January 2018. Structural drawings of the buildings are mentioned in [15].

In general, the surveyed buildings have two thicknesses of masonry wall. The exterior walls are $250 \mathrm{~mm}$ thick and the interior walls are $125 \mathrm{~mm}$ thick. The walls are made of burnt clay brick. The compressive strength of these types of bricks is expected to be $15 \mathrm{MPa}$. The mortar strength is expected to be between 3 and $5 \mathrm{MPa}$. The expected masonry prism compressive strength may vary between 6 and $10 \mathrm{MPa}$. Therefore, the shear strength of the masonry infill is taken as $0.2 \mathrm{~N} / \mathrm{mm}^{2}$ as proposed in Table 1 .

The distribution of the seismic capacities of the investigated buildings in Dhaka that are calculated based on the proposed method is shown in Figure 22. The average $I_{s}$-index is 0.19 with a standard deviation of 0.11
Seismic Capacity of Buildings and Comparison with Nearby Countries

There have been no major earthquakes in Bangladesh in the last 100 years. As Bangladesh and Nepal both border India, there is a similar construction practice for RC buildings with masonry infill walls.

The design spectral acceleration curves are calculated based on the 2015 BNBC Code (draft) for soil type SC for Dhaka city. The design spectra are compared with the response spectra of the 2015 Nepal Earthquake in Figure 23.

A comparison of the observed damage in buildings in Nepal with the seismic capacities of the investigated buildings in Dhaka is shown in Figure 24. The Bangladeshi buildings have very low seismic capacity when compared to Nepalese buildings and may suffer severe damage if an earthquake similar to the Nepal Earthquake were to occur. These results emphasize the importance and urgency for earthquake retrofitting in Bangladesh, otherwise the ratio of damage and percentage of total number of causalities could be more than that of the Nepal 2015 earthquake.

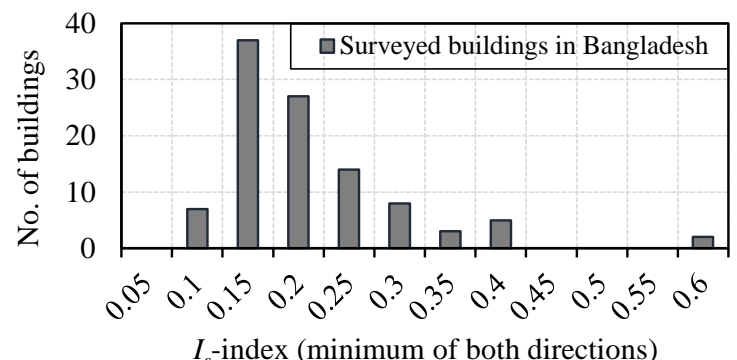

Figure 22: Distribution of $I_{s}$-index of the investigated buildings in Dhaka city.

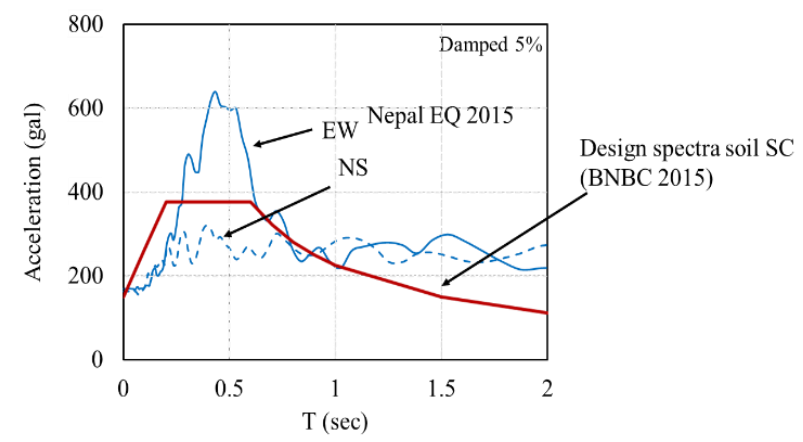

Figure 23: Response spectra for Dhaka (based on 2015 $B N B C$ draft) and Nepal $E Q$.

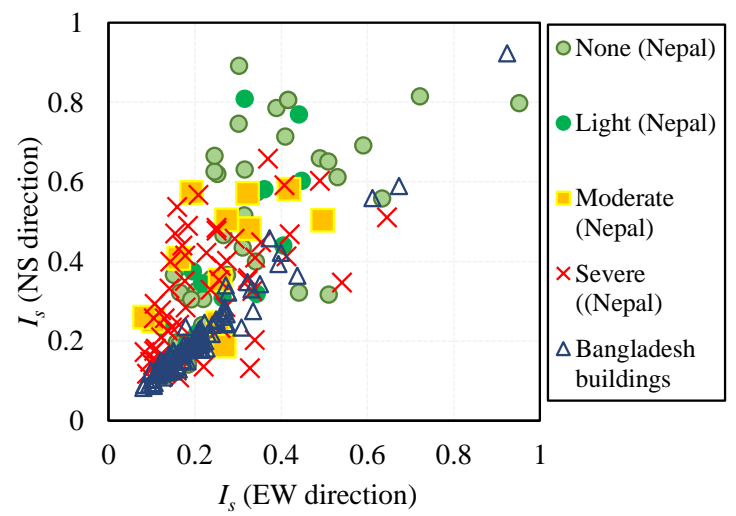

Figure 24: Comparison of existing RC buildings in Bangladesh and damage observed in Nepal EQ. 


\section{CONCLUSIONS}

This study proposes a simplified procedure to include masonry infill walls into the Japanese Seismic Evaluation Standard of existing RC buildings [1]. The seismic capacities $\left(I_{s}\right.$-index) of masonry infilled RC frame buildings in several countries are investigated and the following conclusions are drawn:

1 There is a clear relation between the decrease of $I_{s}$ index and damage level in the investigated buildings in the three past earthquakes, which are: Nepal Earthquake in 2015, Ecuador Earthquake in 2016 and Taiwan Earthquake in 2016.

2 Severe damage is concentrated in buildings with $I_{s}$ smaller than 0.3. On the other hand, buildings with $I_{s}$ index greater than 0.6 avoided severe damage. Hence, an $I_{s}$ index of 0.6 for masonry infilled buildings would be sufficient to avoid severe damage in case of major earthquakes with ground motion levels comparable to those studied in this paper.

3 The unfortunate reality is that most of the investigated buildings have seismic capacity indices smaller than 0.6. These results emphasize the importance and urgency of earthquake retrofitting particularly in developing countries.

It should be noted that several assumptions have been made for the calculations as noted before, such as in-plane failure precedes the out of plane failure based on damage reported in literature [6-8]. However, this is not a general rule, and should be taken with precautions especially with masonry infill with gaps around the frames, large openings and masonry walls without bounding frame.

In addition, the investigated buildings in this paper are only RC frame buildings with masonry infill. However, the proposed seismic capacity method considering masonry infill could be also applied to RC buildings with $\mathrm{RC}$ walls and $\mathrm{RC}$ frames since it is within the scope of the Japanese Building Assessment Standard [1]. The calculations of strength (C-index) and ductility (F-index) for RC walls can be used as indicated in the Japanese Standard [1].

\section{ACKNOWLEDGMENTS}

This is an updated and extended version of a paper presented at the Eleventh Pacific Conference on Earthquake Engineering (PCEE) at Auckland in April 2019.

The study was supported by the SATREPS project TSUIB (project in Bangladesh) 2015 directed by Professor Nakano Yoshiaki, University of Tokyo and JSPS KAKENHI Grant Number JP 19K15070. This support is gratefully acknowledged.

\section{REFERENCES}

1 Japan Building Disaster Prevention Association (2001). "Standard for Seismic Evaluation of Existing Reinforced Concrete Buildings". Japan Building Disaster Prevention Association (JBDPA), Tokyo, Japan (In Japanese).

2 Maeda M, Alwashali H, Suzuki K and Takahashi K (2012). "Damage of RC building structures due to 2011 East Japan Earthquake" Proceedings of 2012 Structures Congress, ASCE, Chicago USA, Vol 2.

3 Paulay T and Priestley MJN (1992). "Seismic Design of Reinforced Concrete \& Masonry Buildings". John Wiley \& Sons.

4 Aoyama HA (1981). "Method for the evaluation of the seismic capacity of existing reinforced concrete buildings in Japan". Bulletin of New Zealand National Society for Earthquake Engineering, 14(3): 105-130
5 Otani S (2000). "Seismic vulnerability assessment methods for buildings in Japan". Earthquake Engineering and Engineering Seismology, 2(2): 47-56

6 Mehrabi AB, Shing PB, Schuller M and Noland J (1996). "Experimental Evaluation of Masonry infilled RC Frames". ASCE Journal of Structural Engineering, 122(3): 228-237.

7 Jin KW, Choi H and Nakano Y (2016). "Experimental study on lateral strength evaluation of unreinforced masonryinfilled RC frame". Earthquake Spectra, 32: 1725-1747.

8 Suzuki T, Choi H, Sanada Y, Nakano Y, Matsukawa K, Paul D, Gülkan P and Binici B, (2017). "Experimental Evaluation of the In-Plane Behavior of Masonry Wall Infilled RC Frames". Bulletin of Earthquake Engineering, 15(10): 4245-4267.

9 Kakaletsis DJ and Karayannis CG (2009). "Experimental investigation of infilled reinforced concrete frames with openings". ACI Structural Journal, 106(2): 132-141.

10 Blackard B, Willam K and Mettupalayam S (2009). "Experimental observations of masonry infilled RC frames with openings". ACI Special Publication, 265: 199-222.

11 Al-Nimry HS (2014). "Quasi-Static Testing of RC Infilled Frames \& Confined Stone-Concrete Bearing Walls". Journal of Earthquake Engineering, 18:1-23.

12 Imran L and Aryanto A (2009). "Behavior of Reinforced Concrete Frames In-Filled with Lightweight Materials under Seismic Loads". Civil Engineering Dimension, 11(2):69-77.

13 Bose S and Durgesh CR (2016). "Lateral Load Behavior of an Open-Ground-Story RC Building with AAC Infills in Upper Stories". Earthquake Spectra, 32(3): 1653-1674.

14 Alwashali H, Sen D, Jin K and Maeda M (2019). "Experimental investigation of influences of several parameters on seismic capacity of masonry infilled reinforced concrete frame". Engineering Structures, 189: $11-24$.

15 Alwashali H (2018). "Seismic Capacity Evaluation of Reinforced Concrete Buildings with Unreinforced Masonry Infill in Developing Countries". Ph.D. Thesis, Tohoku Univ, Tohuku, 10/2018

16 American Society of Civil Engineers (2007). "ASCE/SEI 41-06: Seismic Rehabilitation of Existing Buildings". American Society of Civil Engineers (ASCE), Reston, Virginia, USA, $428 \mathrm{pp}$.

17 New Zealand Society for Earthquake Engineering (2017). "The seismic assessment of existing buildings Part C7". New Zealand Society for Earthquake Engineering (NZSEE), Wellington, NZ.

18 Datacenter Hub, Purdue University; NCREE (2016) "Performance of RC Buildings in the 2016 Taiwan EQ" https://datacenterhub.org/resources/14098.

19 Chungwook S, Enrique V, John PS, Pedro R, Pujol S, Aishwarya YP and Lucas L (2016). "Performance of Lowrise RC Buildings in the 2016 Ecuador EQ" Datacenter Hub, https://datacenterhub.org/resources/14160.

20 Prateek P, Pranjal PS and Praveen PS (2016). "Performance of Masonry Structures in Nepal" Datacenter Hub, https://datacenterhub.org/resources/14223.

21 Sen D, Alwashali H, Jin K and Maeda M (2018). "Contribution of surrounding RC frame and masonry wall in lateral resistance of masonry infilled RC frame". Proceedings of the Annual Japan Concrete Institute Annual Conference, Kobe, Japan.

22 Dawe JL and Seah CK (1989). "Out-of-plane resistance of concrete masonry infilled panels". Journal of the Canadian Society of Civil Engineering, 16: 854-864.

23 Angel R, Abrams D, Shapiro D, Uzarski J and Webster M (1994). "Behaviour of reinforced concrete frames with 
masonry infills". Report No. UILU-ENG-94-2005. Department of Civil Engineering, University of Illinois, Urbana-Champaign, IL, USA.

24 Flanagan RD and Bennett RM (1999). "Bidirectional behaviour of structural clay tile infilled frames". ASCE Journal of Structural Engineering, 125(3): 236-244.

25 Chiou TC, Hwang SJ, Chung LL, Tu YS, Shen WC and Weng PW (2017). "Preliminary Seismic Assessment of Low-Rise RC Buildings in Taiwan". Proceeding of World Conference of Earthquake Engineering, 9-13 January 2017, Santiago, Chile.

26 Cevallos O, David J, Carlos Á and Ximena A (2017). "Production and quality levels of construction materials in
Andean regions: A case study of Chimborazo, Ecuador". Journal of Construction in Developing Countries. 22(1): 115-136.

27 Dizhur D, Dhakal R, Bothara J and Ingham J (2016). "Building typologies and failure modes observed in the 2015 Gorkha (Nepal) earthquake". Bulletin of New Zealand National Society for Earthquake Engineering, 49(2): 211232.

28 Pradhan S, Fukui S, Sanada Y and Kusunoki K (2017). "Seismic performance evaluation of an RC building with brick walls in Nepal". Proceeding of Annual Meeting of AIJ, Paper No. 23451. 